\title{
First record of the Indo-Pacific humpback dolphins (Sousa chinensis) southwest of Hainan Island, China
}

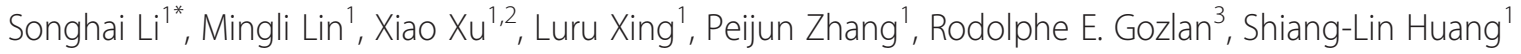 \\ and Ding Wang ${ }^{4}$
}

\begin{abstract}
Background: Populations of Indo-Pacific humpback dolphins (Sousa chinensis) in China were known to be distributed from the Beibu Gulf near the border with Vietnam to the mouth of the Yangtze River. According to existing studies, the waters around Hainan Island, China, were not considered to be part of the humpback dolphins' distribution.

Results: In 2014, for the first time, we recorded humpback dolphins in waters southwest of Hainan Island.

Conclusions: This record expands the known southern distribution range of this dolphin in Chinese waters by more than $300 \mathrm{~km}$.
\end{abstract}

Keywords: Chinese white dolphin, Marine mammals, Conservation, Distribution

\section{Background}

Stranding and whaling records indicate the presence of more than 40 marine mammal species in Chinese waters (Wang, 2012), some of which are of high conservation value and listed by the Chinese State Council as Grade 1 National Key Protected Animals since 1988. This is, for example, the case for both the Yangtze River dolphin (Lipotes vexillifer), or baiji, and the Indo-Pacific humpback dolphin (locally called Chinese white dolphin, Sousa chinensis, Osbeck, 1765), which was classified as Near Threatened by the International Union for Conservation of Nature in 2001 (IUCN, 2001) as a single species, and evaluated as Vulnerable by a recent assessment of the species. Humpback dolphins (genus Sousa) are small odontoctes that occur in coastal waters of the eastern Atlantic, Indian and western Pacific Oceans (Ross et al. 1994; Jefferson and Karczmarski, 2001; Parra and Ross, 2009). Evidence from skeletal and external morphology, coloring, genetics and distribution support the recognition of three species of humpback dolphins in India-Pacific waters, which are $S$. plumbea, S. sahulensis, and S. chinensis (Jefferson and

\footnotetext{
* Correspondence: LISH@IDSSE.AC.CN

'Sanya Key Laboratory of Marine Mammal and Marine Bioacoustics, Institute of Deep-sea Science and Engineering, Chinese Academy of Sciences, Sanya 572000, China

Full list of author information is available at the end of the article
}

Rosenbaum, 2014). Specifically, S. chinensis has a relatively larger dorsal fin with no prominent hump and largely white adult coloring. It ranges from coastal waters of Southeast Asia to central China (Jefferson and Rosenbaum 2014). If assessed separately, in light of likely taxonomic distinctness (Jefferson and Rosenbaum, 2014; Reeves et al. 2008), S. chinensis would qualify as Volnerable (Reeves et al. 2008). The Yangtze River dolphin is now functionally extinct (Turvey et al. 2007; Guo, 2006) and, as such, conservation efforts have been concentrated on S. chinesis populations, which could still benefit from a targeted conservation strategy (Jefferson and Hung, 2004). However, the current rapid economic growth in China that can be seen through its recent increase in coastal economic activities (e.g. fishing, tourist boating, island construction) has directly impacted its marine environment. Such rapid changes have resulted in habitat degradation including noise pollution, harassment and overfishing of prey species with knock-on effects on marine mammal populations (Jefferson and Hung, 2004) throughout Chinese waters.

The current census of S. Chinensis identified a few populations in Chinese waters, albeit with a sparse distribution (Fig. 1a; Jefferson, 2000; Jefferson and Hung, 2004; Chen et al. 2009). It was assumed that $S$. chinensis was sporadically distributed along the coast, from the 


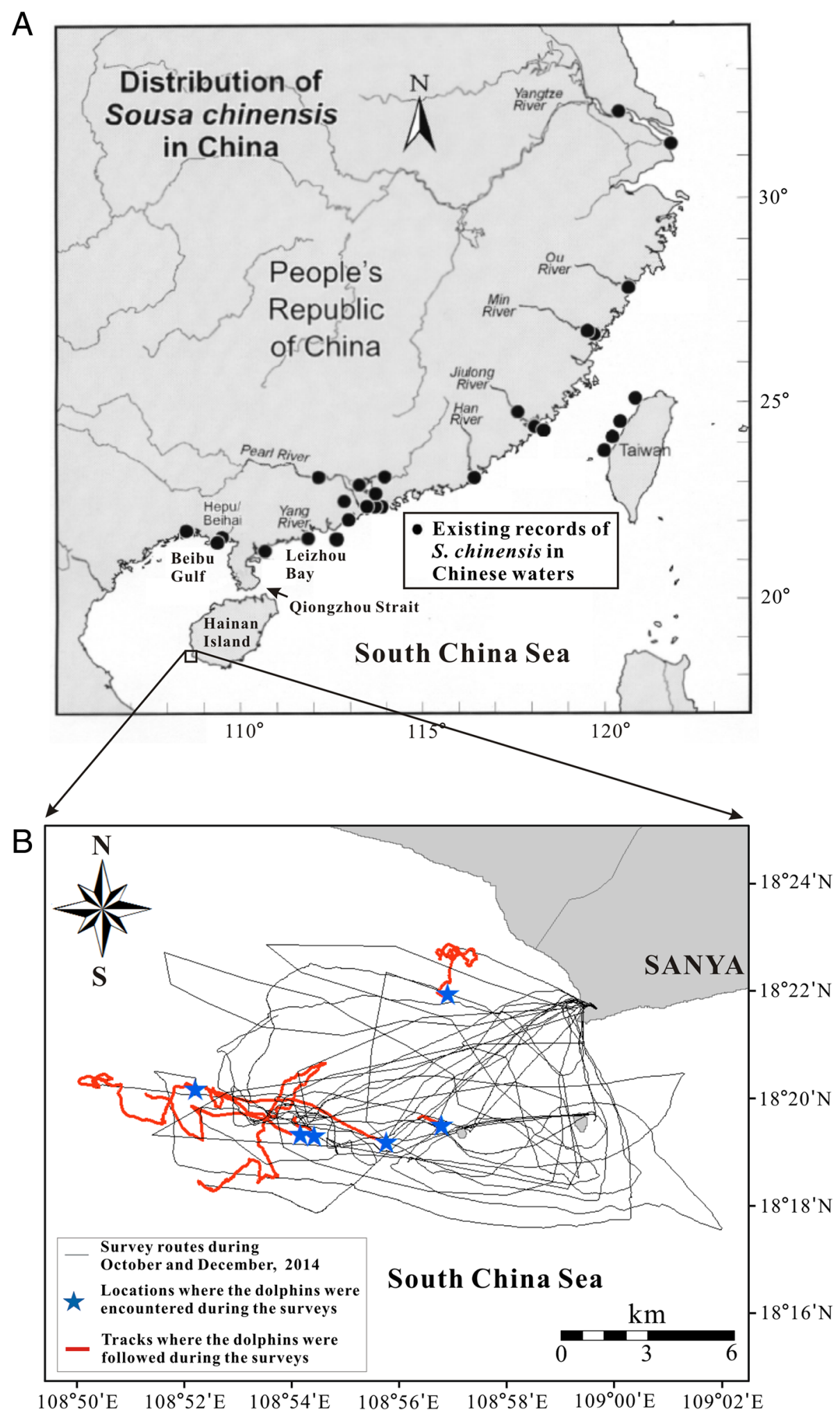

Fig. 1 a Existing records of populations of Indo-Pacific humpback dolphins Sousa chinensis in Chinese waters, adapted from Jefferson and Hung (2004); b location of the newly recorded $\mathrm{S}$. chinensis 
Beibu Gulf near the Vietnamese border to the mouth of the Yangtze River (Fig. 1a; Corkeron et al. 1997; Jefferson and Leatherwood, 1997; Jefferson and Karczmarski, 2001), with the southernmost records being in the Beibu Gulf (Wang and Sun, 1982).

On the basis of the best available information about $S$. chinensis and its habitat along the coast of mainland China (Jefferson and Rosenbaum 2014), waters around Hainan Island which are isolated from mainland China by the Qiongzhou Strait, where water is deep and appears to be a barrier for movement of this species (Chen et al. 2009), did not include distribution records of S. chinensis (Jefferson and Hung 2004, Chen et al. 2009). However, targeted marine mammal surveys are too few and only carried out in certain waters along the coast of mainland China despite a need for a comprehensive understanding of S. Chinensis' distribution in Chinese waters to underpin a robust and sound conservation plan.

Here we aimed to carry out further S. Chinensis' population surveys in Chinese waters. Specifically, in waters where, despite possible sightings by local fishermen, this species has not yet been officially recorded.

\section{Methods}

According to a recent survey of fishermen carried out around the coast of Hainan Island, China, it was expected that humpback dolphins were appearing in waters southwest of Hainan Island. Boat-based visual surveys were thus set up to confirm the presence of these dolphins in these waters. The field surveys were conducted under China's Wildlife Protection Act, 1989, Implementation By-law on Aquatic Wildlife Conservation, and marine mammal research permit No. SIDSSE-SYLL-MMMBL-01 from Institute of Deep-sea Science and Engineering of the Chinese Academy of Sciences. The surveyed waters are located about $40 \mathrm{~km}$ west of the city of Sanya, which is the most famous tropical tourist resort in China. The area is characterized by sandy and muddy bottom structure with water depth between approximately 5 and $30 \mathrm{~m}$. There is no large estuary close to the investigated waters.

Monthly boat-based visual surveys of 4 to 5 days were carried out between August and December 2014. The surveys were conducted using a 9-m-long fishing boat, traveling at about $10 \mathrm{~km} / \mathrm{h}$. The survey team consisted of a boat skipper who was an experienced local fisherman and a minimum of three observers. To increase the chance of sighting dolphins, survey transects were not previously designed but more or less followed the suggestion of the boat skipper with a prior assumption to encounter dolphins during each survey. A minimum of two observers searched the waters using unaided eyes or binoculars (FUIINON, $7 \times 50$ FMT-SX) from an eye height of about $3 \mathrm{~m}$ above sea level. Two observers searched a quadrant covering $90^{\circ}$ of arc from the center line to the sides of the boat on each side of the boat. Information about date, time, GPS position, water depth, species and number of animals was recorded on a standardized effort log by the third observer at $30 \mathrm{~min}$ intervals or whenever the survey boat made a major course change or dolphins were observed. Once the dolphins were observed, as many highquality photographs and videos as possible were taken of the animals by slowly following the animal groups.

\section{Results}

All survey efforts were conducted in Beaufort Sea states of $1-3$. The survey effort generally lasted for 5 to $9 \mathrm{~h}$ (mean $\pm \mathrm{SD}=6.7 \pm 1.4 \mathrm{~h}$ ) along an approximately 40 to $80-\mathrm{km}$ route $($ mean $\pm \mathrm{SD}=55.4 \pm 15.6 \mathrm{~km})$ each day depending on weather condition. The first sighting of $S$. chinensis with more than 20 individuals was made on 20 October 2014. The second sighting was made the following day, 21 October 2014 with more than 30 individuals. In subsequent survey efforts during November and December 2014, the dolphins were sighted about once every other day in the surveyed area. In total, there were six dolphin sightings recorded over a 13-day survey from October to December 2014. Water depth at sighting points was shallower than $20 \mathrm{~m}$ (mean $\pm \mathrm{SD}=15.2 \pm 1.5 \mathrm{~m})$. Survey details are presented in Table 1. Routes of surveys (grey lines), locations (blue stars) and tracks (thick pink lines) where $S$. chinensis were sighted and slowly followed between October and December 2014 are shown in Fig. 1b. Each sighting consisted of approximately 10 to 40 individuals with several fission/fusion societies of 3 to 6 dolphins with white, pink, or gray skin color. Dolphins with gray skin color generally have relatively shorter body length compared to those with white or pink skin color. Occasionally, newborns with gray skin color and body length shorter than half of that of the adults with white or pink color were observed. Pictures of the observed dolphins are presented in Fig. 2 as examples.

\section{Discussion and conclusions}

Observed dolphins possessed the typical external morphology and coloring of S. chinensis (Fig. 2; Jefferson and Leatherwood, 1997). Thus, these sightings consist of the first record of $S$. chinensis in the coastal waters southwest of Hainan Island, as until now the waters were considered void of S. chinensis (Fig. 1a; Jefferson and Hung, 2004; Zhang and Tang, 2008; Chen et al. 2009) despite previous records along the coastal waters of Vietnam within the Beibu Gulf (Smith et al. 2003). This new record expands the currently known Chinese distribution range of this lion-sized mammalian predator by more than $300 \mathrm{~km}$ south. However, its population status, size, age class composition, habitat range, annual or seasonal present pattern, possible prey, threatening factors (such as by-catch, vessel 
Table 1 Survey effort (time duration, length), sighting location, sighting number and number of animals estimated in each sight between August and December 2014

\begin{tabular}{|c|c|c|c|c|c|c|}
\hline \multirow[t]{2}{*}{ Date } & \multirow{2}{*}{$\begin{array}{l}\text { Time duration } \\
\text { (hrs) }\end{array}$} & \multirow{2}{*}{$\begin{array}{l}\text { Length } \\
(\mathrm{km})\end{array}$} & \multicolumn{2}{|c|}{ Sighting location } & \multirow{2}{*}{$\begin{array}{l}\text { Sighting } \\
\text { number }\end{array}$} & \multirow{2}{*}{$\begin{array}{l}\text { Number of } \\
\text { animals sighted }\end{array}$} \\
\hline & & & Longitude & Latitude & & \\
\hline $10 / 08 / 2014$ & 6.5 & 52 & $\mathrm{~N} / \mathrm{A}$ & $N / A$ & 0 & 0 \\
\hline $11 / 08 / 2014$ & 6 & 41 & N/A & N/A & 0 & 0 \\
\hline 14/08/2014 & 7.5 & 71 & N/A & N/A & 0 & 0 \\
\hline $16 / 08 / 2014$ & 9 & 79 & N/A & N/A & 0 & 0 \\
\hline 21/09/2014 & 2 & 12 & N/A & N/A & 0 & 0 \\
\hline 22/09/2014 & 6 & 55 & N/A & N/A & 0 & 0 \\
\hline 24/09/2014 & 7.5 & 69 & N/A & N/A & 0 & 0 \\
\hline 26/09/2014 & 8.5 & 76 & N/A & N/A & 0 & 0 \\
\hline 27/09/2014 & 7 & 68 & $\mathrm{~N} / \mathrm{A}$ & N/A & 0 & 0 \\
\hline 19/10/2014 & 6 & 50 & N/A & N/A & 0 & 0 \\
\hline 20/10/2014 & 7.5 & 57 & $108^{\circ} 52.219^{\prime}$ & $18^{\circ} 20.194^{\prime}$ & 1 & $20-30$ \\
\hline $21 / 10 / 2014$ & 7.5 & 55 & $108^{\circ} 55.772^{\prime}$ & $18^{\circ} 19.198^{\prime}$ & 1 & $30-40$ \\
\hline 23/10/2014 & 8 & 70 & N/A & N/A & 0 & 0 \\
\hline $11 / 11 / 2014$ & 5 & 38 & $109^{\circ} 54.720^{\prime}$ & $18^{\circ} 19.657^{\prime}$ & 1 & 8 \\
\hline $12 / 11 / 2014$ & 6.5 & 60 & N/A & N/A & 0 & 0 \\
\hline $15 / 11 / 2014$ & 7.5 & 50 & N/A & N/A & 0 & 0 \\
\hline $16 / 11 / 2014$ & 6 & 38 & $108^{\circ} 56.919^{\prime}$ & $18^{\circ} 21.956^{\prime}$ & 1 & $15-20$ \\
\hline $13 / 12 / 2014$ & 7 & 60 & $108^{\circ} 56.794^{\prime}$ & $18^{\circ} 19.523^{\prime}$ & 1 & $15-20$ \\
\hline $14 / 12 / 2014$ & 6 & 44 & N/A & N/A & 0 & 0 \\
\hline $15 / 12 / 2014$ & 8 & 72 & N/A & N/A & 0 & 0 \\
\hline $18 / 12 / 2014$ & 6 & 56 & $\mathrm{~N} / \mathrm{A}$ & N/A & 0 & 0 \\
\hline $20 / 12 / 2014$ & 6 & 45 & $108^{\circ} 54.170^{\prime}$ & $18^{\circ} 19.339^{\prime}$ & 1 & 12 \\
\hline
\end{tabular}

collisions and overfishing of prey) and connections to other known populations remain to be investigated.

Most information on ecology of $S$. chinensis comes from studies conducted in Hong Kong and surrounding waters, and in recent years in Taiwan and some areas of the mainland coast of China. Published studies showed that S. chinensis movements tend to be over relatively small areas with an average of $135 \mathrm{~km}^{2}$ (Hung 2008). The present new sightings are located nearly more than $300 \mathrm{~km}$ away from previously known habitat of $S$. chinensis. This coast is a prime tourist destination and hosts dense human populations, especially during the winter tourist season. However, although these waters are generally subject to high economic pressure and coastal development, the Beibu
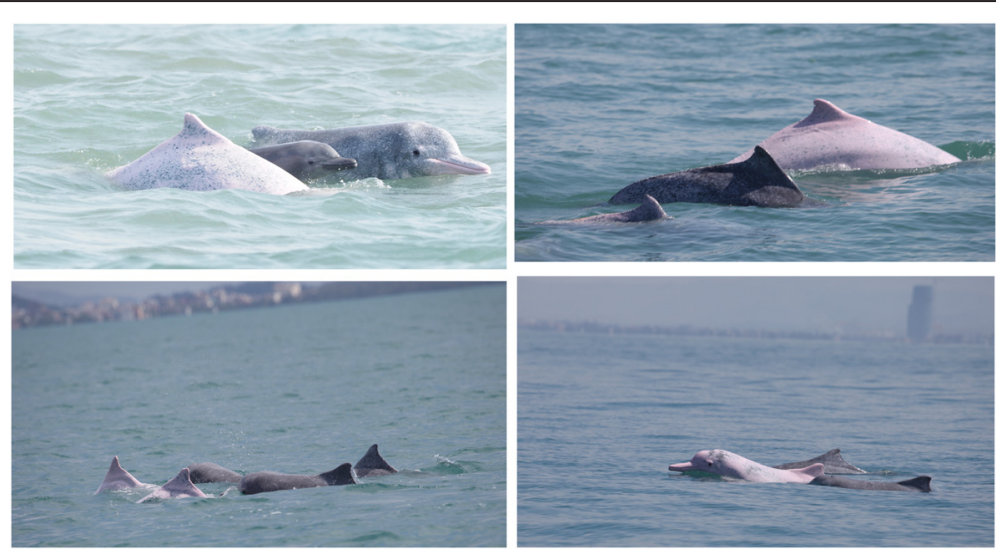

Fig. 2 Pictures of S. chinensis taken during the present boat surveys 
Gulf is shallow (i.e. mean of $38 \mathrm{~m}$ ) and is an important fishing ground with abundant fishery resources (Qiao and Lin 2007) and thus potentially consists of an ecologically important habitat for small dolphins. Previous studies indicated that habitat of S. chinensis consists of shallow, coastal marine waters and especially waters in and around large estuaries (Jefferson and Karczmarski 2001). In Hong Kong waters, it appears to occur anywhere where there is a riverine influence, but does not occur in a strictly-marine environment (Jefferson 2000). There is no large estuary around the sighting area, however, with these new sightings in an area generally shallower than $20 \mathrm{~m}$, which is similar to those previously recorded in Hong Kong and surrounding waters (Jefferson and Karczmarski 2001; Chen et al. 2011), it confirms a preference of these dolphins in shallow waters. Although fish catch and species components in the present surveyed area were not yet quantitatively investigated, shoals of small fish were frequently observed during the surveys.

The previous lack of records for S. chinensis in waters southwest of Hainan island may be due to limited past marine mammals survey efforts most likely arising from a low understanding by local societies of the need for dolphin conservation. National and local government management agencies would be partly accountable if some $S$. chinensis' populations were facing a risk of extinction before they could even be studied and protected. In effect, conservation action is vulnerable to a knowledge gap and researchers must consider the intrinsic characteristics of their species to raise public perception effectively (Gozlan et al. 2013). However, communication to the wider scientific community is the first stepping-stone to ignite a policy change. In addition, we will appeal to the regional government to take action and support extensive and substantive national and international collaboration with scientists and conservationists to put in place a set of conservation actions and effectively protect $S$. chinesis populations in the border area against extinction.

\section{Competing interests}

The authors declare that they have no competing interests.

\section{Authors' contribution}

LS and LM designed and carried out the field surveys. XX participated in the field surveys. XL and ZP provided logistics supports during the study. LS analyzed the data and drafted the manuscript. LM participated in the data analysis. GRE helped to draft the manuscript. HSL participated in the survey design. WD participated in the study design and coordination. All authors read and approved the final manuscript.

\section{Acknowledgements}

The field survey was supported by the Ocean Park Conservation Foundation of Hong Kong (OPCFHK, Nos. MM03-1415, MM02-1516), the National Natural Science Foundation of China (Nos. 41306169, 41422604, and 41406182), the "Hundred Talents Program" of the Chinese Academy of Sciences (Nos. SIDSSE-BR-315 201201, Y410012), the Knowledge Innovation Program of the Chinese Academy of Sciences (No. SIDSSE-316 201210), Marine Development by Science and Technology Project of Hainan Province (XH201423), Advanced Project in Young Talent of Sanya Institute of Deep-sea Science and Engineering,
Chinese Academy of Sciences (SIDSSE-QN-201304), and Informatizational special fund of the Chinese Academy of Sciences (No. XXH12504-3-20).

\section{Author details}

${ }^{1}$ Sanya Key Laboratory of Marine Mammal and Marine Bioacoustics, Institute of Deep-sea Science and Engineering, Chinese Academy of Sciences, Sanya 572000, China. ${ }^{2}$ University of Chinese Academy of Sciences, Beijing 100039, China. Institut de Recherche pour le Développement, Unité Mixte de Recherche Biologie des Organismes et Ecosystèmes Aquatiques (IRD 207, CNRS 7208, MNHN, UPMC) Muséum National d'Histoire Naturelle, 75231 Paris Cedex, France. ${ }^{4}$ The Key Laboratory of Aquatic Biodiversity and Conservation of Chinese Academy of Sciences, Institute of Hydrobiology, Chinese Academy of Sciences, Wuhan 430072, China.

Received: 29 January 2016 Accepted: 8 February 2016

Published online: 08 March 2016

\section{References}

Chen B, Zheng D, Yang G, Xu X, Zhou K. Distribution and conservation of the Indo-Pacific humpback dolphin in China. Integrative Zoology. 2009:4:240-7.

Chen T, Qiu YS, Jia XP, Hung SK, Liu WH. Distribution and group dynamics of Indo-Pacific humpback dolphins (Sousa chinensis) in the western Pearl River Estuary, China. Mamm Biol. 2011;76:93-6.

Corkeron PJ, Morissette NM, Porter L, Marsh H. Distribution and status of humpback dolphins, Sousa chinensis, in Australian waters. Asian Marine Biology. 1997;14:49-57.

Gozlan RE, Burnard D, Andreou D, Britton JR. Understanding the threats posed by non-native species: public vs conservation managers. PloS One. 2013;8: e53200. doi:10.1371/journal.pone.0053200.

Guo J. River dolphins down for the count, and perhaps out. Science. 2006;314:1860.

Hung SKY. Habitat use of Indo-Pacific humpback dolphins (Sousa chinensis) in Hong Kong. Ph.D. thesis, University of Hong Kong, Hong Kong. 2008. p. 253.

IUCN. IUCN Red List Categories and Criteria: Version 3.1. Switzerland and Cambridge, UK: IUCN Species Survival Commission. IUCN, Gland; 2001.

Jefferson TA. Population biology of the Indo-Pacific hump-backed dolphin in Hong Kong waters. Wildl Monogr. 2000;144:1-65.

Jefferson TA, Hung SK. A review of the status of the Indo-Pacific humpback dolphin (Sousa chinensis) in Chinese waters. Aquat Mamm. 2004;30:149-58.

Jefferson TA, Karczmarski L. Sousa chinensis. Mammal Species. 2001;655:1-9.

Jefferson TA, Leatherwood S. Distribution and abundance of Indo-Pacific humpbacked dolphins (Sousa chinensis Osbeck, 1975) in Hong Kong waters. Asian Marine Biology. 1997;14:93-110.

Jefferson TA, Rosenbaum HC. Taxonomic revision of the humpback dolphins (Sousa spp.), and description of a new species from Australia. Marine Mammal Science. 2014;30:1494-541.

Osbeck P. Reise nach Ostindien und China (English translation 1771). Rostok, Germany: Koppe; 1765.

Parra GJ, Ross GJB. Humpback dolphins Sousa chinensis and S. teuszii. In: Perrin WF, Würsig B, Thewissen JGM, editors. Encyclopedia of marine mammals. 2nd ed. London, UK: Academic; 2009. p. 576-82.

Qiao Y. and Lin Z. (2007) The relationship between the main features of landform, the distribution of bottom sediment and fishery distribution. Transactions of Oceanology and Limnology 232-238. In Chinese with English abstract. http://en.cnki.com.cn/Article en/CJFDTotal-HYFB2007S1034.htm.

Reeves RR, Dalebout ML, Jefferson TA, Karczmarski L, Laidre K, O'Corry-Crowe G, Rojas-Bracho L, Secchi ER, Slooten E, Smith BD, Wang JY, Zhou K 2008. Sousa chinensis. The IUCN Red List of Threatened Species 2008: e.T20424A9197694. http://www.iucnredlist.org/details/20424/0.

Ross GJB, Heinsohn GE, Cockcroft VG. Humpback dolphins Sousa chinensis (Osbeck, 1765), Sousa plumbea (G. Cuvier, 1829) and Sousa teuszii (Kükenthal, 1892). In: Ridgway SH, Harrison R, editors. Handbook of marine mammals. Volume 5. The first book of dolphins. London, UK: Academic; 1994. p. 23-42.

Smith BD, Braulik G, Jefferson TA, Chung BD, Vinh CT, Du DV, Hanh BV, Trong PD, Ho DT, Quang W. Notes on two cetacean surveys in the gulf of Tonkin, Vietnam. Raffles Bull Zool. 2003;51:165-71.

Turvey ST, Pitman RL, Taylor BL, Barlow J, Akamatsu T, Barrett LA, Zhao X, Reeves RR, Stevart BS, Wang K, Wei Z, Zhang X, Pusser LT, Richlen M, Brandon JR, Wang D. First human-caust extinction of a cetacean species? Biol Lett. 2007;3:537-40. 
Wang P. Chinese Cetaceans. Beijing, China: Chemical Industry Publishing House; 2012. In Chinese.

Wang P, Sun J. Studies on the Zhonghua white dolphin, Sousa chinensis from the South China Sea. Transactions of the Liaoning Zoological Society. 1982;3:67-74. In Chinese.

Zhang L, Tang S. Distribution of Chinese white dolphin in the coast waters of China. Journal of Oceanography in Taiwan Strait. 2008;27:79-86. In Chinese.

Submit your next manuscript to BioMed Central and we will help you at every step:

- We accept pre-submission inquiries

- Our selector tool helps you to find the most relevant journal

- We provide round the clock customer support

- Convenient online submission

- Thorough peer review

- Inclusion in PubMed and all major indexing services

- Maximum visibility for your research

Submit your manuscript at www.biomedcentral.com/submit 